\title{
Associated factors of access to health care among foreign residents living in Aichi Prefecture, Japan: Secondary data analysis of informal free consultations organized by a non-governmental organization
}

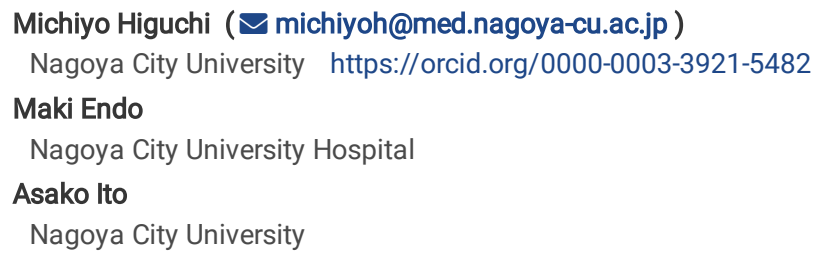

\section{Research}

Keywords: Migrants, Access to health care, Universal Health Coverage, Japan, Non-governmental organization

Posted Date: December 17th, 2020

DOI: https://doi.org/10.21203/rs.3.rs-129403/v1

License: (c) (i) This work is licensed under a Creative Commons Attribution 4.0 International License. Read Full License 


\section{Abstract \\ Background}

In Japan, foreign residents, and particularly new arrivals in the country, experience barriers to health care and show poorer health outcomes when compared to Japanese nationals. The health-care-related situation for foreign residents in Japan has been characterized by drastic changes over time; thus, there is difficulty identifying individuals who are "left behind" by the system. In this study, we aimed to identify, among foreign residents who attended informal free medical consultations, factors associated with "being advised to visit a medical facility" and "being referred to a medical facility," which represented hypothetical proxy indicators of barriers to health care.

\section{Methods}

Secondary data analyses were conducted using the activity records of a non-governmental organization that provides free consultations targeting foreign residents in various locations in Aichi Prefecture, Japan. Participant characteristics, including insurance coverage, were determined. Bivariable and multivariable analyses were performed to identify factors associated with having barriers to health care.

\section{Results}

Among 608 extracted cases, $81.7 \%$ were covered by Japanese public insurance, and insurance coverage was associated with sex and region of origin. During the consultations, $164(27.5 \%)$ cases were advised to visit a medical facility, and $72(11.8 \%)$ were referred to a medical facility. Those who were not covered by public insurance showed a 1.56-times (95\% confidence interval [CI]: 1.19-2.05) higher prevalence of being advised to visit a medical facility when compared to those who were covered by public insurance. Unemployed people and students were more likely to be referred to a medical facility than were professional workers; the prevalence ratios were 3.28 (95\% Cl: 1.64-6.57) and 2.77 (95\% Cl: 1.18-6.46), respectively.

\section{Conclusions}

Information from the non-governmental organization revealed the diversity of foreign residents who require informal health-care-related consultations. Although the majority were insured, almost $30 \%$ were advised to visit a medical facility, which implied that they had had limited access to the formal healthcare system before availing of the free consultations. The findings highlight specific groups who may be vulnerable, and it is important to provide these groups with the necessary support, based on updated evidence, to ensure that no one is "left behind."

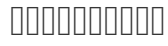

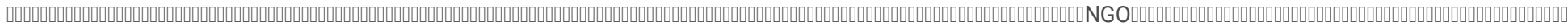

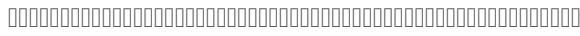

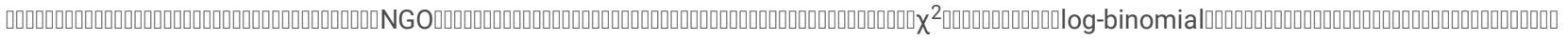

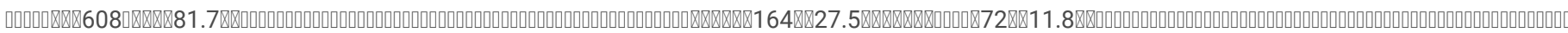

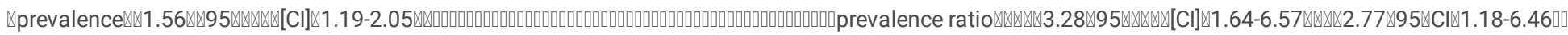

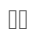

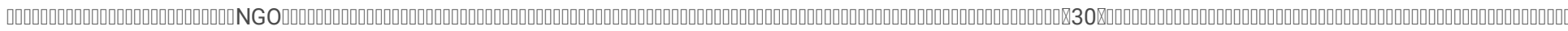

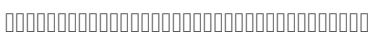

\section{Background}

"Leave no one behind," which represents the goal of eradicating poverty, discrimination, and exclusion and of reducing inequalities and vulnerabilities, is a core element of the global community's agenda (1). To help realize this vision, universal health coverage (UHC) has been included as a target of the United Nation's Sustainable Development Goals, and achieving UHC has become a priority in the health sectors of many countries (2). In this global context, Japan is recognized as a country where universal public insurance coverage was implemented in the country almost 60 years ago (3). However, despite this long-term existence of the universal health insurance systemin Japan, a health gap exists, with some population groups having little access to coverage (4). In particular, migrants and immigrants are considered to be vulnerable groups in regard to both access to health care and overall health (5-8).

Up to March 2019, Japan maintained a strict policy regarding foreign workers, except those who held visas based on their civil status (this approach was officially termed "based on status or position") and or those engaged in professional work or designated activities. Approximately 40 years ago, few foreign residents lived in Japan with the exception of "special permanent residents"; these were individuals (and their descendants) who stayed in Japan after losing their Japanese nationality when the Treaty of San Francisco took effect. Since the 1980s, however, the number of "newcomers" has been increasing, mainly as a result of various socio-economic circumstances, such as a shortage of labor in Japan and the country's buoyant economy $(9,10)$. In 1990, the Japanese government adopted a new policy regarding immigrants with Japanese heritage, enabling them and their families to obtain residence status (11-13). In 1993, a new residential qualification, "technical intern," was established. Technical interns are not officially laborers; however, they comprise part of the workforce in 
Japan $(12,14)$. Another surge of newcomers has been the "students" who came to Japan as a result of the government's " 300,000 International Students Plan," which was introduced in $2008(15,16)$. In 1990, the total number of foreign residents in Japan exceeded one million, and 15 years later it reached two million (17). By the end of 2019, foreign residents numbered 2,933,137(18), representing 2.3\% of the total population in Japan. "Newcomers" have outnumbered special permanent residents since the early 1990s (19). Among all foreign residents, "general permanent residents" (permanent residents other than special permanent residents) are now the most prevalent group (27.0\%), followed by "technical interns" (14.0\%), and "students" (11.8\%) (18). Japanese society must now respond to this rapid increase in the total number as well as diversity of foreign residents to ensure that people can coexist in the country (20). In this regard, maintaining the population's health is one of the most urgent social issues.

Since 2012, under the terms of the Japanese public insurance system, foreigners who reside in Japan for three months or longer are eligible for National Health Insurance. Those who are employed, regardless of nationality, are covered by employees' health insurance (21). Taking all of these insurance systems in combination suggests that $80 \%$ of foreign residents are now covered by a Japanese public insurance scheme $(7,8,22)$; however, there are no official data on this. While the number of newcomers has increased rapidly, the characteristics of foreign residents living in Japan and their situations have also been drastically changing. It has been reported that foreign residents, and particularly newcomers, despite being covered by public insurance, continue to face barriers to health care and show poorer health outcomes than Japanese nationals $(23,24)$.

In addition to the formal arrangements made by local governments, non-governmental organizations (NGOs) and non-profit organizations (NPOs; hereafter simply referred to as "NGOs") provide support for foreigners' health. Some of these NGOs provide informal, free medical check-ups and consultations. These NGO-organized free check-ups/consultations (hereafter referred to as "free consultations") are external to the formal health system in Japan (25, 26). The free consultations are not usually held in medical facilities (instead, public buildings such as community centers, schools, and churches are used); this means that the volunteer doctors who participate in these consultations do not have access to the appropriate equipment to provide full services for attendees. These NGOs visit various locations in their areas, typically visiting each place once or twice a year, and offer simple examinations and advice. During the free consultations, some attendees are advised to visit a medical facility that is part of the formal health system in order to undergo further examination and/or receive treatment. As people with no barriers to obtaining health care through the formal health system would be likely to visit official medical facilities rather than wait for a free consultation, it can be assumed that attending free consultations and being referred to a medical facility indicates that the attendee was unable to visit a medical facility until they had the opportunity to attend the free consultation.

In the present study, using a dataset from an NGO that provides free medical check-ups in Aichi Prefecture (which has the second-largest foreign population in Japan (18)), we aimed to identify, among foreign residents who attended free consultations, factors associated with "being advised to visit a medical facility" and "being referred to a medical facility"; these factors were considered to represent negative indicators of access to health care. Before the main analyses were performed, we determined the characteristics of the participants in terms of their health-insurance coverage, which is believed to influence access to health care. Replies from referral facilities were also reviewed to determine whether participants, after their referral, had entered the formal health-care system. As studies regarding access to health care among foreign residents in Japan remain limited, the current study will provide knowledge regarding the individuals who are actually "left behind," as well as information regarding the support such people require.

\section{Methods}

Study design and dataset

Secondary data analyses were conducted using the activity records of an NGO located in Aichi Prefecture, Japan. The NGO, Medical Information Center, Aichi (MICA), has provided foreign residents with medical information and free monthly consultations since 1998. Supported by volunteer doctors, dentists, and nurses, as well as non-medical volunteers, the free consultations are provided in various locations in Aichi Prefecture, with each location being visited in rotation. The documentation for these consultation activities comprises a four-page form that the MICA staff members and volunteers complete for each attendee. The pages cover: 1) personal information, including sex, age, date of birth, nationality, occupation, years living in Japan, whether the attendee is covered under a Japanese public insurance scheme, medical history, family medical history, complaints and symptoms; 2) lifestyle, 3) data obtained through physical check-ups (height, weight, blood pressure, pulse rate, body temperature, and urine analysis results) and the results of the consultation with the doctor, including an overall assessment (i.e., the actions the attendee should take); and 4) oral check-ups and the results of consultations with a dentist, with an overall assessment (the actions the attendee should take). The form is available in 10 different languages (English, Portuguese, Spanish, Chinese, Korean, Vietnamese, Filipino, Indonesian, Burmese, and Thai), which ensures that most attendees can understand the questions. All of the information gathered on these forms is entered into a data-management program by MCIA staff members. For the present study, anonymous data of all adults (aged 18 years or older) who participated in the free monthly consultation activities between 2012 and 2016 were extracted from the full dataset; this was performed under the terms of a data-use agreement between the first author and the NGO (MICA). We used 2012 as the start date for the data collection because in 2012 the Japanese Government made a legislative change that allowed foreign residents who lived in Japan for three months or longer to apply for National Health Insurance (previously, only foreign residents who had lived in Japan for one year or longer were eligible.) Cases were excluded if the age was unknown (four cases), nationality was Japanese (16 cases), the participant was a traveler (three cases), and if all records except attributes were missing (one case). Thus, of a total of 632 cases, 608 were used for the analyses.

Data cleaning and definitions

Region of origin was defined based on the nationality recorded on the form and categorized based on United-Nations-recognized regions, unless the nationality was Brazilian, Chinese, Filipino, Vietnamese, or a high-income country that is defined by the World Bank. As Brazilian, Chinese, Filipino, and Vietnamese were the four major groups, they were treated as a single category. "Other Asia" featured 68 participants from South Asia (five countries), 34 from South-East Asia, except Vietnam and the Philippines, (three countries), two from West Asia (one country), and one from Central Asia (one country). 
Participants included in the "other" region were as follows: 35 from Latin America, except Brazil, (five countries), six from East Africa, three from West Africa, three from North Africa, one from Central Africa, two from Russia, and one from Melanesia.

In the data-collection form, attendees' occupation was determined using an open-ended, self-reported answer and, for the present study, we developed occupational categories based on these answers. If the type of factory work or construction work was recorded, or if the occupation was simply recorded as "factory," the participant was categorized as engaging in "factory or construction work." If part-time or contingent work (Arubaito, Paato, or Haken, in Japanese) was recorded as an occupation, the participant was categorized as having a "non-regular job." "Trainee" and "intern" were combined to form "trainee/intern." These three categories were then further grouped into the category "labor and non-regular," because they often overlap and are used interchangeably in daily conversation. Professional workers, such as teachers, engineers, and company workers, were also combined because they are considered to represent the formal sector. Housewives and the unemployed were combined because these people usually stay home and, again, these terms are sometimes used interchangeably in daily conversation. "Other" included nine people engaged in "service," seven helpers (care assistants), four people engaged in religion-related work, three salespeople, three businesspeople, three cooks, two refugees, two volunteers, one babysitter, and one diplomat. Two occupation records could not be categorized, and were also included in "other."

All cases for which there were any records on the third page of the form were defined as "had a medical consultation." Two items were used as the variables of interest and considered as negative indicators of having barriers to health care: 1) "being advised to visit a medical facility" (attributed if the participant was advised to visit a medical facility); and 2) "being referred to a medical facility" (attributed if the participant was referred to a medical facility, with or without a referral letter). We assumed that participants who were advised or referred did not have easy access to the formal health-care system before attending the NGO's consultations. Participants identified as 2) were part of 1), but were considered more serious cases.

\section{Data analysis}

First, participant characteristics (sex, age group, region of origin, occupation, whether he/she was covered by a Japanese public insurance scheme, and time living in Japan) were described. Second, to understand the associations between insurance coverage and participant characteristics, each variable, with the exception of insurance coverage, was analyzed in terms of insurance coverage using chi-square tests. Third, the two indicators of barriers to health care ("being advised to visit a medical facility" and "being referred to a medical facility") were analyzed in terms of participant characteristics using chi-square tests. Fourth, log-binomial regression analyses were performed to calculate the prevalence ratios (PRs) of "being advised to visit a medical facility" and "being referred to a medical facility" for each participant characteristic. Variables that showed, in the chi-square tests, statistical associations for each of the two access indicators were included in the model. Furthermore, if the participants were referred to a medical facility with or without a referral letter, the recorded consequences were described. Stata SE version 12.1 (Stata Corp) was used for all statistical analyses.

\section{Results}

Participant characteristics

One-third (34.0\%) of the participants were under 30 years of age. Two-thirds of the cases (67.8\%) were Vietnamese, Filipino, Brazilian, or Chinese. Almost $30 \%$ did not report their jobs. The second-largest occupation group was laborers and non-regular workers (25.0\%), followed by professional/company workers (24.3\%; the majority of whom were teachers, engineers, and translators). Over one-third (34.7\%) had lived in Japan for five years or longer, and almost onequarter $(24.5 \%)$ for 10 years or longer (Table 1 ). 
Table 1

Participants characteristics among foreign residents who participated in free consultation activities held in Aichi Prefecture from 2012 to 2016

\begin{tabular}{|c|c|c|}
\hline Characteristics & Frequency & $\%$ \\
\hline \multicolumn{3}{|l|}{ Sex } \\
\hline Female & 346 & 56.9 \\
\hline Male & 262 & 43.1 \\
\hline \multicolumn{3}{|l|}{ Age group } \\
\hline-29 years old & 207 & 34.1 \\
\hline 30-39 years old & 176 & 29.0 \\
\hline 40-49 years old & 131 & 21.6 \\
\hline 50- years old & 94 & 15.5 \\
\hline \multicolumn{3}{|l|}{ Region of origin } \\
\hline Vietnam & 123 & 20.2 \\
\hline Philippines & 114 & 18.8 \\
\hline Brazil & 105 & 17.3 \\
\hline China & 70 & 11.5 \\
\hline Other Asia & 105 & 17.3 \\
\hline High-income country & 40 & 6.6 \\
\hline Other & 51 & 8.4 \\
\hline \multicolumn{3}{|l|}{ Occupation } \\
\hline Labour/non-regular ${ }^{a}$ & 152 & 25.0 \\
\hline Professional/company & 148 & 14.3 \\
\hline Student & 31 & 5.1 \\
\hline Unemployed $^{\mathrm{b}}$ & 58 & 9.5 \\
\hline Other & 37 & 6.1 \\
\hline No answer & 182 & 29.9 \\
\hline \multicolumn{3}{|c|}{ Duration of living in Japan (years) } \\
\hline$<1$ year & 83 & 13.7 \\
\hline$\geqq 1$ year, $<5$ years & 222 & 36.5 \\
\hline$\geqq 5$ year & 211 & 34.7 \\
\hline Unknown & 92 & 15.1 \\
\hline \multicolumn{3}{|c|}{ Coverage of a Japanese public health insurance } \\
\hline Covered & 497 & 81.7 \\
\hline Not covered & 101 & 16.6 \\
\hline Unknown & 10 & 1.6 \\
\hline \multicolumn{3}{|l|}{ alncluding trainee/intern } \\
\hline bIncluding housewife & & \\
\hline
\end{tabular}

Associations between insurance coverage and participant characteristics

Of the 598 participants whose data included information insurance coverage, over four-fifths (81.7\%) were covered by a Japanese public insurance scheme. Insurance coverage was associated with sex and region of origin; however, it was not associated with age group, occupation category, or years living in Japan (Table 2). 
Table 2

Coverage under Japanese public insurance by participant characteristics among foreign residents who participated in free consultation activities held in Aichi Prefecture from 2012 to $2016\left(\mathrm{~N}=598^{\mathrm{a}}\right)$

\begin{tabular}{|c|c|c|c|c|c|}
\hline \multirow[t]{4}{*}{ Characteristics } & \multicolumn{4}{|c|}{$\begin{array}{l}\text { Coverage under Japanese } \\
\text { public insurance }\end{array}$} & \multirow[t]{4}{*}{ p-value ${ }^{b}$} \\
\hline & \multirow{2}{*}{\multicolumn{2}{|c|}{$\begin{array}{l}\text { Not covered } \\
(\mathrm{N}=101)\end{array}$}} & \multirow{2}{*}{\multicolumn{2}{|c|}{$\begin{array}{l}\text { Covered } \\
(\mathrm{N}=497)\end{array}$}} & \\
\hline & & & & & \\
\hline & $\mathrm{n}$ & $\%$ & $\mathrm{n}$ & $\%$ & \\
\hline \multicolumn{6}{|l|}{ Sex } \\
\hline Female & 42 & 12.4 & 298 & 87.7 & \multirow[t]{2}{*}{$<0.01$} \\
\hline Male & 59 & 22.9 & 199 & 77.1 & \\
\hline \multicolumn{6}{|l|}{ Age group } \\
\hline-29 years old & 34 & 16.7 & 170 & 83.3 & \multirow[t]{4}{*}{0.41} \\
\hline 30-39 years old & 23 & 13.4 & 149 & 86.6 & \\
\hline 40-49 years old & 26 & 20.0 & 104 & 80.0 & \\
\hline 50 -years old & 18 & 19.6 & 74 & 80.4 & \\
\hline \multicolumn{6}{|l|}{ Region of origin } \\
\hline Vietnam & 20 & 16.8 & 99 & 83.2 & \multirow[t]{7}{*}{0.01} \\
\hline Philippines & 26 & 23.0 & 87 & 77.0 & \\
\hline Brazil & 13 & 12.4 & 92 & 87.6 & \\
\hline China & 2 & 3.0 & 65 & 97.0 & \\
\hline Other Asia & 23 & 22.3 & 80 & 77.7 & \\
\hline High-income country & 7 & 17.5 & 33 & 82.5 & \\
\hline Other & 10 & 19.6 & 41 & 80.4 & \\
\hline \multicolumn{6}{|l|}{ Occupation } \\
\hline Labour/non-regular ${ }^{c}$ & 25 & 16.8 & 124 & 83.2 & \multirow[t]{6}{*}{0.10} \\
\hline Professional/company & 18 & 12.2 & 130 & 87.4 & \\
\hline Student & 3 & 9.7 & 28 & 90.3 & \\
\hline Unemployed $^{\mathrm{d}}$ & 12 & 21.8 & 43 & 78.2 & \\
\hline Other & 11 & 30.6 & 25 & 69.4 & \\
\hline No answer & 32 & 17.9 & 147 & 82.1 & \\
\hline \multicolumn{6}{|c|}{ Duration of living in Japan ${ }^{\mathrm{e}}$} \\
\hline$<1$ year & 16 & 19.8 & 65 & 80.3 & \multirow[t]{3}{*}{0.67} \\
\hline$\geqq 1$ year, $<5$ years & 34 & 15.6 & 184 & 84.4 & \\
\hline$\geqq 5$ years & 37 & 17.6 & 173 & 82.4 & \\
\hline \multicolumn{6}{|c|}{${ }^{\text {aT } T e n ~ p a r t i c i p a n t s ~ w e r e ~ e x c l u d e d ~ b e c a u s e ~ i t ~ w a s ~ n o t ~ k n o w n ~ i f ~ t h e y ~ w e r e ~ c o v e r e d ~ b y ~ J a p a n e s e ~ p u b l i c ~ i n s u r a n c e . ~}$} \\
\hline \multicolumn{6}{|l|}{${ }^{\mathrm{b}}$ Chi-square test } \\
\hline \multicolumn{6}{|l|}{ 'Including trainee/intern } \\
\hline \multicolumn{6}{|l|}{${ }^{\mathrm{d}}$ Including housewives } \\
\hline eUnknown for 87 partici & & & & & \\
\hline
\end{tabular}

Associations between access to health care and participant characteristics

Of the 596 participants who had received medical consultations, $164(27.5 \%)$ were advised to visit a medical facility. Occupation category and insurance coverage were associated with being advised to visit a medical facility $(p=0.01$ and $p<0.01$, respectively; Table 3$)$. Meanwhile, $72(11.8 \%)$ cases were referred 
to a medical facility, and the occupation category also showed a statistical association with referral $(p<0.01$; Table 4). 
Table 3

Whether advised to visit a medical facility according to participant characteristics among foreign residents who participated in free consultation activities held in Aichi Prefecture from 2012 to $2016\left(\mathrm{~N}=596^{\mathrm{a}}\right)$

\begin{tabular}{|c|c|c|c|c|c|}
\hline \multirow[t]{4}{*}{ Characteristics } & \multicolumn{4}{|c|}{$\begin{array}{l}\text { Whether advised to visit } \\
\text { a medical facility }\end{array}$} & \multirow[t]{4}{*}{ p-value ${ }^{b}$} \\
\hline & \multirow{2}{*}{\multicolumn{2}{|c|}{$\begin{array}{l}\text { Yes } \\
(N=164)\end{array}$}} & \multirow{2}{*}{\multicolumn{2}{|c|}{$\begin{array}{l}\text { No } \\
(N=432)\end{array}$}} & \\
\hline & & & & & \\
\hline & $\mathrm{n}$ & $\%$ & $\mathrm{n}$ & $\%$ & \\
\hline \multicolumn{6}{|l|}{ Sex } \\
\hline Female & 100 & 29.7 & 237 & 70.3 & \multirow[t]{2}{*}{0.18} \\
\hline Male & 64 & 24.7 & 195 & 75.3 & \\
\hline \multicolumn{6}{|l|}{ Age group } \\
\hline-29 years old & 54 & 26.3 & 151 & 73.7 & \multirow[t]{4}{*}{0.36} \\
\hline $30-39$ years old & 41 & 23.8 & 131 & 76.2 & \\
\hline $40-49$ years old & 39 & 30.5 & 89 & 69.5 & \\
\hline 50 -years old & 30 & 33.0 & 61 & 67.0 & \\
\hline \multicolumn{6}{|l|}{ Region of origin } \\
\hline Vietnam & 30 & 24.6 & 92 & 75.4 & \multirow[t]{7}{*}{0.59} \\
\hline Philippines & 37 & 33.3 & 74 & 66.7 & \\
\hline Brazil & 27 & 26.2 & 76 & 73.8 & \\
\hline China & 15 & 22.4 & 52 & 77.6 & \\
\hline Other Asia & 27 & 26.0 & 77 & 74.0 & \\
\hline High-income country & 14 & 35.0 & 26 & 65.0 & \\
\hline Other & 14 & 28.6 & 35 & 71.4 & \\
\hline \multicolumn{6}{|l|}{ Occupation } \\
\hline Labour/non-regular ${ }^{\mathrm{C}}$ & 36 & 24.2 & 113 & 75.8 & \multirow[t]{6}{*}{0.01} \\
\hline Professional/company & 33 & 22.5 & 114 & 77.6 & \\
\hline Student & 9 & 29.0 & 22 & 71.0 & \\
\hline Unemployed $^{d}$ & 26 & 46.4 & 30 & 53.6 & \\
\hline Other & 14 & 37.8 & 23 & 62.2 & \\
\hline No answer & 46 & 26.1 & 130 & 73.9 & \\
\hline \multicolumn{6}{|c|}{ Coverage under Japanese public insurance ${ }^{\mathrm{e}}$} \\
\hline Covered & 121 & 24.9 & 366 & 75.2 & \multirow[t]{2}{*}{$<0.01$} \\
\hline Not covered & 41 & 41.0 & 59 & 59.0 & \\
\hline \multicolumn{6}{|l|}{ Duration of living in Japan ${ }^{f}$} \\
\hline$<1$ year & 23 & 27.7 & 60 & 72.3 & \multirow[t]{2}{*}{0.90} \\
\hline$\geqq 1$ year, $<5$ years & 59 & 26.7 & 162 & 73.3 & \\
\hline \multicolumn{6}{|c|}{ a'Twelve participants were excluded because it was not known if they had been advised to visit a medical facility. } \\
\hline \multicolumn{6}{|l|}{${ }^{\mathrm{b}}$ Chi-square test } \\
\hline \multicolumn{6}{|l|}{ 'Including trainee/intern } \\
\hline \multicolumn{6}{|l|}{${ }^{d}$ Including housewives } \\
\hline \multicolumn{6}{|l|}{ eUnknown for 9 participants } \\
\hline fUnknown for 86 participants & & & & & \\
\hline
\end{tabular}




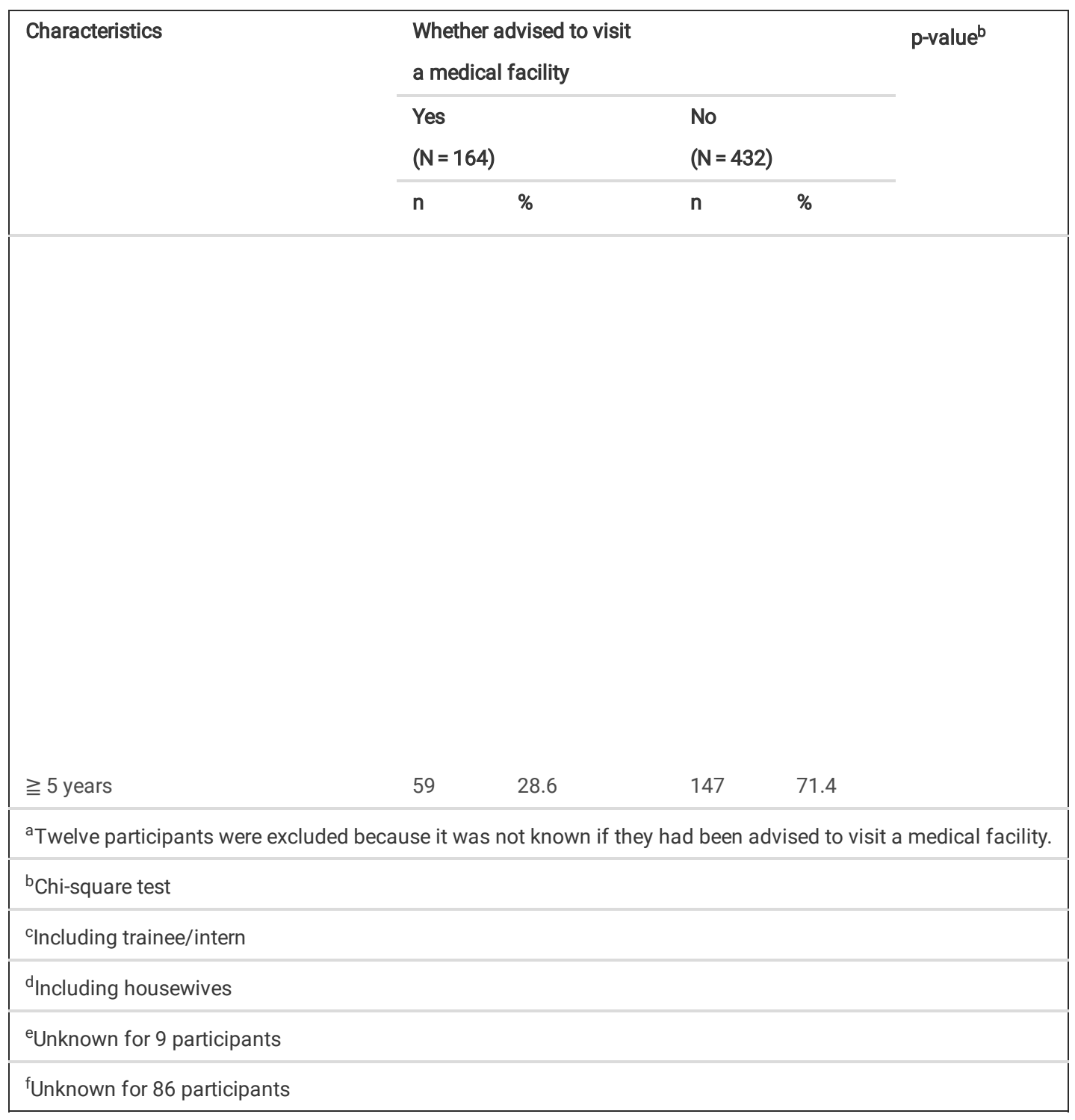


Table 4

Whether referred to a medical facility according to participant characteristics among foreign residents who participated in free consultation activities held in Aichi Prefecture from 2012 to $2016\left(\mathrm{~N}=596^{\mathrm{a}}\right)$

\begin{tabular}{|c|c|c|c|c|c|}
\hline \multirow[t]{4}{*}{ Characteristics } & \multicolumn{4}{|c|}{$\begin{array}{l}\text { Whether referred to } \\
\text { a medical facility }\end{array}$} & \multirow[t]{4}{*}{ p-value ${ }^{b}$} \\
\hline & \multirow{2}{*}{\multicolumn{2}{|c|}{$\begin{array}{l}\text { Yes } \\
(N=72)\end{array}$}} & \multirow{2}{*}{\multicolumn{2}{|c|}{$\begin{array}{l}\text { No } \\
(N=524)\end{array}$}} & \\
\hline & & & & & \\
\hline & $\mathbf{n}$ & $\%$ & $\mathbf{n}$ & $\%$ & \\
\hline \multicolumn{6}{|l|}{ Sex } \\
\hline Female & 45 & 13.4 & 292 & 86.6 & \multirow[t]{2}{*}{0.28} \\
\hline Male & 27 & 10.4 & 232 & 89.6 & \\
\hline \multicolumn{6}{|l|}{ Age group } \\
\hline-29 years old & 25 & 12.2 & 180 & 87.8 & \multirow[t]{4}{*}{0.98} \\
\hline 30-39 years old & 22 & 12.8 & 150 & 87.2 & \\
\hline 40-49 years old & 15 & 11.7 & 113 & 88.3 & \\
\hline 50-years old & 10 & 11.0 & 81 & 89.0 & \\
\hline \multicolumn{6}{|l|}{ Region of origin } \\
\hline Vietnam & 17 & 13.9 & 105 & 86.1 & \multirow[t]{7}{*}{0.25} \\
\hline Philippines & 14 & 12.6 & 97 & 87.4 & \\
\hline Brazil & 7 & 6.8 & 96 & 93.2 & \\
\hline China & 6 & 9.0 & 61 & 91.0 & \\
\hline Other Asia & 19 & 18.3 & 85 & 81.7 & \\
\hline High-income country & 4 & 10.0 & 36 & 90.0 & \\
\hline Other & 5 & 10.2 & 44 & 89.8 & \\
\hline \multicolumn{6}{|l|}{ Occupation } \\
\hline Labour/non-regular $^{\mathrm{C}}$ & 15 & 10.1 & 134 & 89.9 & \multirow[t]{6}{*}{$<0.01$} \\
\hline Professional/company & 12 & 8.2 & 135 & 91.8 & \\
\hline Student & 7 & 22.6 & 24 & 77.4 & \\
\hline Unemployed $^{\mathrm{d}}$ & 15 & 26.8 & 41 & 73.2 & \\
\hline Other & 4 & 10.8 & 33 & 89.2 & \\
\hline No answer & 19 & 10.8 & 157 & 89.2 & \\
\hline \multicolumn{6}{|c|}{ Coverage under Japanese public insurance ${ }^{\mathrm{e}}$} \\
\hline Covered & 57 & 11.7 & 430 & 88.3 & \multirow[t]{2}{*}{0.52} \\
\hline Not covered & 14 & 14.0 & 86 & 86.0 & \\
\hline \multicolumn{6}{|l|}{ Duration of living in Japan ${ }^{f}$} \\
\hline$<1$ year & 10 & 12.0 & 73 & 88.0 & \multirow[t]{2}{*}{0.75} \\
\hline$\geqq 1$ year, $<5$ years & 30 & 13.6 & 191 & 86.4 & \\
\hline \multicolumn{6}{|c|}{ aTwelve participants were excluded because it was not known if they had been referred to a medical facility. } \\
\hline \multicolumn{6}{|l|}{${ }^{\mathrm{b}} \mathrm{Chi}$-square test } \\
\hline \multicolumn{6}{|l|}{ 'Including trainee/intern } \\
\hline \multicolumn{6}{|l|}{${ }^{d}$ Including housewives } \\
\hline \multicolumn{6}{|l|}{ eUnknown for 9 participants } \\
\hline fUnknown for 86 participants & & & & & \\
\hline
\end{tabular}




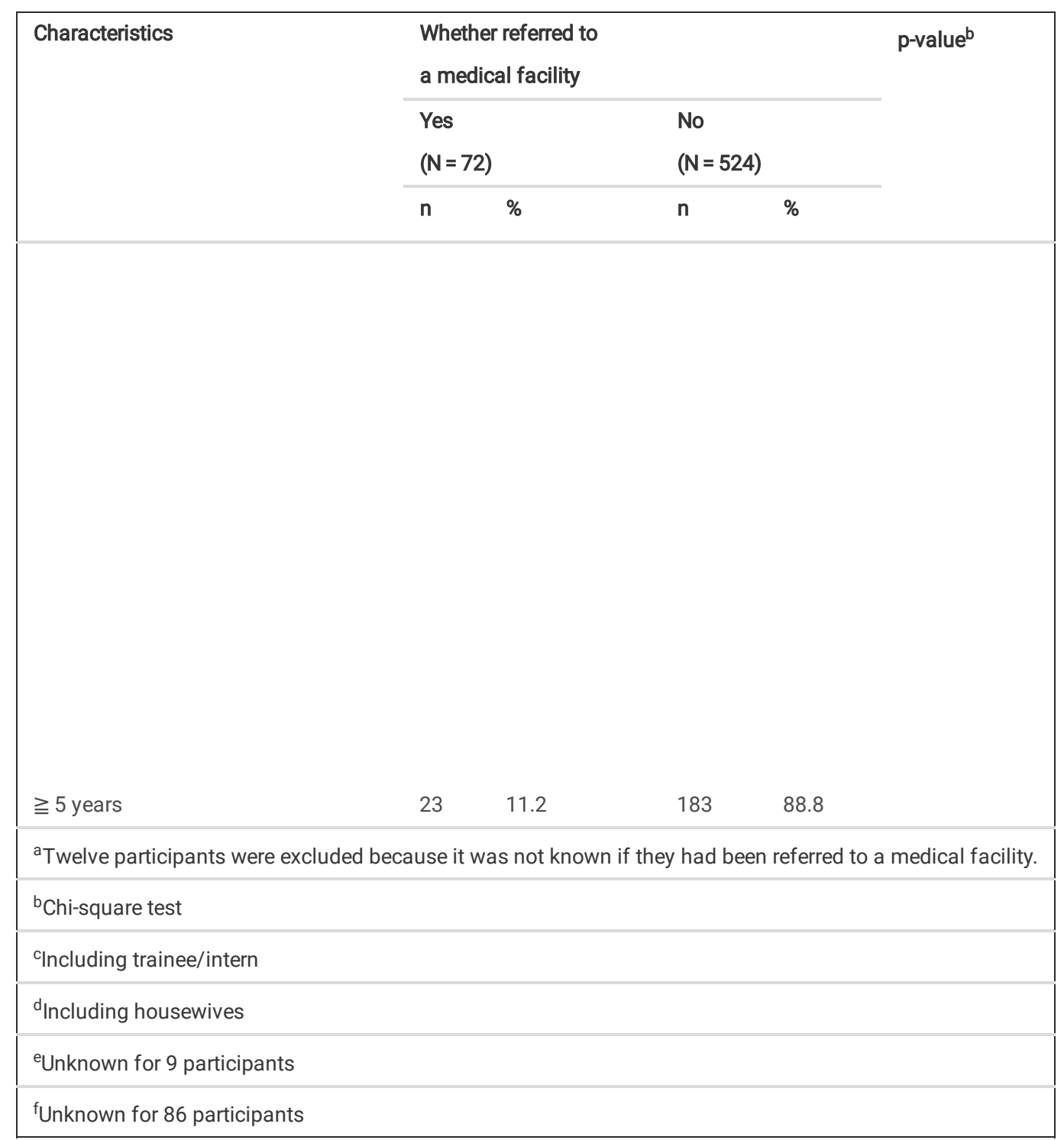

Multiple regression analysis of access to health care

Log-binomial regression analyses showed that unemployed people, including housewives, had higher PRs of being advised to visit a medical facility than did professional/company workers; the adjusted PR was 2.08 (95\% confidence interval [Cl]: 1.40-3.11). Among those who were not covered by public insurance, the prevalence of being advised to visit a medical facility was 1.56 times as high as that for participants who were covered by public insurance ( $95 \%$ Cl: $1.18-$ 2.05). Unemployed people, including housewives and students, were more likely to be referred to a medical facility than were professional/company workers; the PRs were 2.77 (95\% Cl: $1.64-6.57)$ and 3.28 (95\% Cl: 1.18-6.46), respectively (Table 5). 
Table 5

Multiple regression analysis of "being advised to visit a medical facility" and "being referred to a medical facility" among foreign residents who participated in free consultation activities held in Aichi Prefecture from 2012 to 2016

\begin{tabular}{|c|c|c|c|}
\hline \multicolumn{3}{|c|}{ Being advised to visit a medical facility $\left(N=587^{a}\right)$} & \multirow[t]{2}{*}{ p-value } \\
\hline & $a R^{b}$ & $95 \% \mathrm{Cl}$ & \\
\hline \multicolumn{4}{|l|}{ Occupation } \\
\hline Professional/company & \multicolumn{3}{|l|}{ reference } \\
\hline Labour/non-regular ${ }^{c}$ & 1.06 & $0.70-1.60$ & 0.79 \\
\hline Student & 1.28 & $0.69-2.37$ & 0.44 \\
\hline Unemployed $^{d}$ & 2.08 & $1.40-3.11$ & $<0.01$ \\
\hline Other & 1.47 & $0.87-2.49$ & 0.15 \\
\hline No answer & 1.17 & $0.79-1.72$ & 0.43 \\
\hline \multicolumn{4}{|c|}{ Coverage under Japanese public insurance } \\
\hline Covered & \multicolumn{3}{|l|}{ reference } \\
\hline Not covered & 1.56 & $1.19-2.05$ & $<0.01$ \\
\hline \multicolumn{3}{|c|}{ Being referred to a medical facility $\left(N=596^{\mathrm{e}}\right)$} & \multirow[t]{2}{*}{$\mathrm{p}$-value } \\
\hline & PR & $95 \% \mathrm{Cl}$ & \\
\hline \multicolumn{4}{|l|}{ Occupation } \\
\hline Professional/company & ref & & \\
\hline Labour/non-regular ${ }^{c}$ & 1.23 & $0.60-2.54$ & 0.57 \\
\hline Student & 2.77 & $1.18-6.46$ & 0.02 \\
\hline Unemployed $^{d}$ & 3.28 & $1.64-6.57$ & $<0.01$ \\
\hline Other & 1.32 & $0.45-3.87$ & 0.61 \\
\hline No answer & 1.32 & $0.66-2.63$ & 0.43 \\
\hline \multicolumn{4}{|c|}{ PR: prevalence ratio, aPR: adjusted prevalence ratio } \\
\hline \multicolumn{4}{|c|}{ 95\% Cl: 95\% confident interval } \\
\hline \multicolumn{4}{|c|}{$\begin{array}{l}\text { a Twenty-one participants were excluded because it was not known if a) they were covered by Japanese public insurance or b) if they had been advised to } \\
\text { visit a medical facility. }\end{array}$} \\
\hline \multicolumn{4}{|l|}{ bMutually adjusted } \\
\hline \multicolumn{4}{|c|}{ Including trainees/interns } \\
\hline${ }^{\mathrm{d}}$ Including housewives & & & \\
\hline
\end{tabular}

\section{Consequences of the referrals}

Of the 72 people who were referred to a medical facility with or without a referral letter, 11 received replies from a medical doctor. In addition, medical information letters were sent from medical facilities to the NGO for two cases who were not recorded as "referred." The date of the medical visit was known for five of these cases; only one person visited a medical facility within a month of the free consultation. Of the 13 cases, no urgent and/or serious disease was found; however, three people were diagnosed with valvular regurgitation, atrial fibrillation, or a thyroid tumor after further investigation, and were placed under medical observation.

\section{Discussion}

We conducted secondary analyses of data for a diverse sample of foreign residents who attended free medical consultations offered by an NGO in various locations in Aichi Prefecture. Four-fifths of the participants were covered by Japanese public insurance; however, in the consultations with the volunteer doctors over one-fourth of the participants were advised to visit a medical facility. It was assumed that these individuals generally experienced barriers to accessing the formal health-care system. Risk groups regarding being advised to visit a medical facility or being referred to a medical facility were found to be 
people who are uninsured, people who are unemployed, and students. Of the 72 cases who were referred to a medical facility, the NGO received reply letters from medical facilities for just 11 cases.

We found that $81.7 \%$ of the cases in our dataset were covered by Japanese public insurance. Japan implemented universal public insurance coverage in 1961 (3), and in 2012 implemented a law to allow every person living in Japan, regardless of their nationality (but excepting visitors staying for three months or shorter), to receive coverage under a Japanese public insurance scheme (21). As there are numerous insurance schemes in Japan, it is difficult to obtain exact figures regarding coverage among foreign residents. According to reports from some local governments and NGOs, however, it has been estimated that approximately $80 \%$ of foreign residents are covered by a Japanese public insurance scheme $(7,8,22)$. This shows a dramatic improvement in coverage in recent decades, as in 2004 a survey conducted by a local government reported that this figure was $64.4 \%$ (27). The result obtained through the present analysis is similar to the figures presented in these recent reports. Our data also suggest that sex and region of origin are associated with insurance coverage. In addition, those who were uninsured were likely to be advised to visit a medical facility, which was used as a hypothetical proxy indicator of having barriers to accessing formal health care. This is consistent with the findings of a previous study on access to health care among Nepalese residents in Japan (8). The findings of the current study raise four issues. First, one-fifth of the cases were not covered. Second, a high prevalence of non-coverage was found among some specific groups. These two points show gaps in UHC in Japan. Third, insurance coverage was considered to be associated with access to health care. Lastly, but importantly, although the majority of people who attended the NGO-organized free consultations were covered by public insurance, they needed to attend the free consultations, and a relatively large proportion of these individuals were subsequently advised to visit a medical facility. While reducing the number of people who do not have insurance coverage is important, other possible barriers, such as language and emotional barriers, should be identified and then removed, regardless of insurance coverage.

Previous studies on access to health insurance among Latin American residents and on access to health care among Nepalese residents in Japan did not find associations between access variables and employment status $(7,8)$. In contrast, our study suggested that unemployed people, including housewives, represent a high-risk group. Although it is difficult to speculate the underlying reasons, income, which was unknown in our dataset, may have an important effect. In addition, students were found to represent another possible risk group. In May 2019, 312,214 foreign students were living in Japan (28). Among these, 53.2\% were studying at professional training colleges, university preparatory courses, or Japanese-language institutes (28); institutions for which the School Health and Safety Act generally does not apply. According to a 2009 survey conducted by the Association for the Promotion of Japanese Language Education, $66.5 \%$ of the respondents from Japanese-language schools had experienced illness or injury since arriving in Japan; of these, $2.3 \%$ had been hospitalized, $39.8 \%$ had visited medical facilities, and $2.7 \%$ had consulted their school's medical personnel [26]. Further, among this group the most frequent answer to a question regarding the types of treatment used was "self-medication" (44.3\%) (29) Meanwhile, in a survey of students in Japanese-language schools in Tokyo, $48.7 \%$ of the surveyed students reported that they did not think they had access to doctors/health workers (30). In a recent survey by the present authors (not yet published) of Vietnamese and Nepalese students in Japanese-language schools in Nagoya, 20.9\% of the surveyed students reported experiencing unmet health-care needs since arriving in Japan. Notably, access to health care may influence individual and public health outcomes. Foreign students in Japanese language schools have become a target population in regard to measures to address tuberculosis (31), with foreign-born people accounting for a major part of new cases among young generations (32). The government's "300,000 International Students Plan," has led to the arrival in Japan of a cohort of foreign students with diverse characteristics. A survey conducted by a governmental organization suggested that over three-quarters of privately-funded foreign students hold part-time jobs, among which almost $70 \%$ work over 15 hours per week (33); working such relatively long hours while also attempting to fulfill education responsibilities might explain the health-care-related vulnerability among this group. On one hand, systems to accept foreign students should be improved, but on the other, supporters of foreign residents need to recognize the vulnerability of this group.

Over one-third of the participants had lived in Japan for five years or longer. Length of stay in Japan was not associated with our hypothetical indicator of having barriers to health care; this partially disagreed with the findings of a previous study regarding access to health care (8). A possible reason for this is differences regarding target populations and indicators of access to health care. Official statistics show that the proportions of people with "general permanent resident" status and "long-term resident" status in Aichi Prefecture are higher than the national figures; in 2016, "general permanent residents" and "long-term residents" accounted for $42.9 \%$ and $14.6 \%$, respectively, of the "mid to long-term residents" (foreign residents with the exception of "special permanent residents") of Aichi Prefecture, compared with $35.8 \%$ and $8.3 \%$, respectively, for the entire country (34). The high prevalence of long-stay foreign residents appears to be a characteristic of Aichi Prefecture, which may have been reflected in our participants' characteristics. The evidence shows that the attendees of the free consultations included individuals who had lived in Japan for a long time, and these individuals showed no significant differences regarding being advised to visit a medical facility when compared with shorter-term residents. This implies that, for some foreign residents, barriers to health care exist, regardless of the duration of their stay.

Another important finding was that, after volunteer doctors sent attendees to health-care providers in the formal health-care system, few replies were obtained. There are at least two possible explanations for this. First, the patients may not have visited a medical facility as advised; and second, the doctors who received the patients did not issue medical information letters to the NGO. Among the returned letters, we found that some patients had been placed under observation. If these referred patients had not visited a medical facility within an appropriate time, their diagnosis would have been delayed. Practically, it is difficult to track referred patient and to check whether they contacted the formal health-care system. Under the government plan for "Promotion of Multicultural Coexistence," various NGOs, along with local governments, are expected to take a role in addressing livability issues for foreign residents (35); however, to ensure access to health care among foreign residents, better communication between NGOs and the formal health-care system is required.

Cases in the dataset were not randomly sampled from all foreign residents in Aichi Prefecture. Although the free consultations are open to everybody, people with similar attributes might have attended as a group. Consequently, the participant characteristics determined in this research may have been biased. However, compared with the proportions of countries of origin listed for residents of Aichi Prefecture in the government statistics for the corresponding years (36), our data can be considered to better reflect the target population in the prefecture. A venue-based approach for sampling hard-to-reach populations would be an acceptable method of obtaining more accurate data $(37,38)$. It was reported that using only census and vital statistics may not be suitable for capturing 
the reality of the health situations among foreign residents (39). Official data describing access to health care among foreign people remain limited; for example, to the best of our knowledge there are no official data regarding the prevalence of uninsured foreign residents. As previous studies have suggested $(7,30,40)$, migrants are likely to be mobile, meaning it may be difficult to study foreign residents through mail surveys with random sampling. Thus, analysis of alternative data, such as that used in our study, is needed. Although the information we used was not collected for research purposes, our findings are nevertheless informative. As we have shown, analyzing data from NGOs can strengthen understanding of, and foster improvement in, access to health care and health outcomes.

There were some limitations to this study. First, the data were entered by case (consultation), not by person. If the dataset includes many people who attended multiple consultations, the statistical findings may have been overestimated. However, because free consultations are held in different places in Aichi Prefecture over the course of the year, it is unlikely that the number of repeat visitors within one year would be large. Second, our assumption was that those who required free consultations and who were advised to visit a medical facility were likely to have barriers to health care in daily life. Therefore, "being advised to visit a medical facility" and "being referred to a medical facility" were used as a hypothetical proxy indicator of having barriers to the formal healthcare system. It is possible that our assumption was invalid. Although some standardized indicators have been suggested for assessing access to health care, such as service utilization and unmet health care needs $(41,42)$, these are not always available in routine datasets. Therefore, we used a proxy indicator that was available to us and was considered to be reasonable. Third, as a result of language barriers, obtaining reliable answers to some questions from some participants was difficult. For example, occupation was an open-ended, self-report answer, and volunteers (interviewers) sometimes needed to infer attendees' jobs from their responses. Despite these limitations, we believe that this study will be valuable because of its diversity of its participants. Using such datasets, we can grasp situations regarding access to health care among foreign residents. Thus far, a limited number of studies have been published regarding access to health care among foreign residents in Japan. One recent study employed purposive sampling at restaurants to sample Nepalese participants (8), while another study sought to use random sampling, but only targeted Latin Americans in one city (7). In the future, studies with randomly selected data, obtained through collaboration with local governments, will be required for more rigorous analyses.

\section{Conclusion}

Information from an NGO revealed the diversity of foreign residents living in Aichi Prefecture who require informal, free health consultations. Although the majority of the participants were covered by Japanese health insurance, almost $30 \%$ were advised to visit a medical facility, which implied that they had limited access to the formal health-care system before availing of the NGO's consultations. Being advised to visit a medical facility was associated with insurance coverage. Housewives, unemployed people, and students were found to be high-risk groups. The Japanese government has recently decided to accept up to 340,000 foreign workers, including unskilled workers, over five years, beginning in April 2019. Thus, the number of foreign residents will be continuously increasing, and their situations will continue to change. In relation to support for foreign residents, collaboration between NGOs and local governments is an issue in Japanese society $(20,43)$. Various types of collaboration between these parties have been developed to data $(44)$. Collaboration methods could include good utilization of data and collaborative generating of evidence. In addition, better communication between NGOs and health-care providers in the formal health system is required. When such structures have been implemented, developing collaborative studies to understand health-related issues among foreign residents will be the next challenge. It is important that this support is based on updated evidence so that no one is "left behind."

\section{Abbreviations}

Cl: confidence interval; MICA: Medical Information Center, Aichi; NGO: non-governmental organization; NPO: non-profit organization; PR: prevalence ratio; UHC: Universal Health Coverage

\section{Declarations}

\section{Ethics approval and consent to participate}

This study was approved by the ethical committee of the Nagoya City University School of Nursing, Japan (ID: 17009-2) and by a board meeting of MICA on June 10, 2017. Extracted data were anonymous and no researcher knew the names of participants. Based on the agreement between MICA and the first author only researchers approved by the MICA board meeting could access the dataset.

\section{Consent for publication}

Not applicable.

\section{Availability of data and materials}

The datasets generated and/or analyzed during the current study are not publicly available due agreement between the data owner (MICA) and the first author but are available from the corresponding author on reasonable request.

\section{Competing interests}

None declared.

\section{Funding}

This study was funded by Grant-in-Aid for Research in Nagoya City University for Fiscal 2018 (Category 3, Number 15). 


\section{Authors' contributions}

$\mathrm{MH}$ designed the study, EM and $\mathrm{MH}$ cleaned the dataset and $\mathrm{MH}, \mathrm{EM}$ and $\mathrm{AY}$ analysed data. $\mathrm{MH}$ and EM drafted the manuscript. All authors contributed to the writing of the manuscript and approved the final draft.

\section{Acknowledgements}

We are grateful to the Medical Information Center, Aichi (MICA), which gave us the opportunity to analyse valuable data. In particular, we would like to acknowledge the work of Ms. Norimi Fujita and Ms. Michiko Okihashi, MICA office staff members, who have been organizing free monthly consultation activities and managing participant data. We sincerely appreciate the efforts of all the volunteers who have been supporting MICA activities.

\section{References}

1. United Nations. Resolution adopted by the General Assembly on 25 September 2015: Transformaing our world: The 2030 agenda for sustainable development (A/RES/70/1). New York: United Nations; 2015. [Cited 9 Dec 2020]; Available from: https://undocs.org/A/RES/70/1.

2. Kieny MP, Bekedam H, Dovlo D, Fitzgerald J, Habicht J, Harrison G, et al. Strengthening health systems for universal health coverage and sustainable development. Bulletin of the World Health Organization. 2017;95(7):537-9.

3. Ikegami N, Yoo BK, Hashimoto H, Matsumoto M, Ogata H, Babazono A, et al. Japanese universal health coverage: evolution, achievements, and challenges. Lancet (London, England). 2011;378(9796):1106-15.

4. Watanabe R, Hashimoto H. Horizontal inequity in healthcare access under the universal coverage in Japan; 1986-2007. Social Science and Medicine. 2012;75(8):1372-8.

5. Yamamura J, Sawada T. A study on patients with tuberculosis among foreigners overstayed in Japan after expiration of visa-activities over three years [in Japanese]. Kekkaku : [Tuberculosis]. 2002;77(10):671-7.

6. Komatsu R, Sawada T. The role of international migration in infectious diseases: the HIV epidemic and its trends in Japan. International journal of health services : planning, administration, evaluation. 2007;37(4):745-59.

7. Suguimoto SP, Ono-Kihara M, Feldman MD, Kihara M. Latin American immigrants have limited access to health insurance in Japan: A cross sectional study. BMC Public Health. 2012;12:238.

8. Shakya P, Tanaka M, Shibanuma A, Jimba M. Nepalese migrants in Japan: What is holding them back in getting access to healthcare? PLoS One. 2018;13(9):e0203645.

9. Kondo A. Migration and law in Japan. Asia \& the Pacific Policy Studies. 2015;2(1):155-68.

10. Nagayama T. Foreign workers recruiting policies in Japan. Asian and Pacific Migration Journal. 1996;5(2-3):241-64.

11. Mori H. Foreign migrant workers in Japan: Trends and policies. Asian and Pacific Migration Journal. 1995;4(2-3):411-27.

12. Kuwahara Y. Migrant workers in the post-war history of Japan. Japan Labor Review. 2005;2(4):25-47.

13. Tezuka K. Foreign workers in Japan: reality and challanges. Japan Labor Review. 2005;2(4):48-71.

14. Tian Y. Workers by any other name: comparing co-ethnics and 'interns' as labour migrants to Japan. J Ethn Migr Stud. 2019;45(9):1496-514.

15. Student Exchange Office, Student Services Division, Higher Education Bureau. Outline of the student exchange system: study in Japan and abroad. Tokyo: Ministry of Education, Culture, Sports, Science and Technology, Japan; 2008. [Cited 9 Dec 2020]; Available from:

http://www.mext.go.jp/a_menu/koutou/ryugaku/081210/001.pdf.

16. Ministry of Foreign Affairs, Japan. Student exchange programs: Ministry of Foreign Affairs, Japan; 2019. [Cited 9 Dec 2020]; Available from: https://www.mofa.go.jp/policy/culture/people/student/index.html.

17. Immigration Services Agency of Japan. Initiatives to accept new foreign nationals and for the realization of society of harmonious coexistence. Tokyo: Ministry of Justice, Japan; 2020. [Cited 9 Dec 2020]; Available from: http://www.moj.go.jp/content/001308076.pdf.

18. Immigration Services Agency of Japan. Reiwa-gan-nen matsu genzai ni okeru zairyugaikokujnsu ni tsuite [in Japanese] (The number of foreign residents as of the end of 2019): Ministry of Justice, Japan; 2020. [Cited 9 Dec 2020]; Available from:

http://101.110.15.201/isa/publications/press/nyuukokukanri04_00003.html.

19. "Sentakusuru Mirai" linkai (Comittee on "Choosing the future"). Jinko wo meguru genjo to kadai [in Japanese] (Current status and issues regarding population). Sentakusuru mirai - Jinkosuikei kara mietekuru miraizo- (Choosing the future - The future as seen from population estimates). Tokyo: Cabinet Office, Japan; 2015. p. 67-109. [Cited 9 Dec 2020]; Available from: https://www5.cao.go.jp/keizaishimon/kaigi/special/future/sentaku/pdf/all_03.pdf.

20. Director of the International Affairs Office, Local Administration Bureau, Ministry of Internal Affairs and Communications Japan. Chiiki ni okeru tabunkakyosei suishin puran no kaitei ni tsuite [in Japanese] (About revisions of multi-cultural coexistance plans in the community). Tokyo: Ministry of Internal Affairs and Communications, Japan; 2020. [Cited 9 Dec 2020]; Available from: https://www.soumu.go.jp/main_content/000718717.pdf.

21. Niwa M. Zainichigaikokujin no hoken iryo fukushi no hosyo to houtaikei [in Japanese] खSecurity and legal systems of health, medical and welfare for foreign residents in Japan囚. In: Lee S, editor. Zainichigaikokujin no kenkoshien to iryo tsuyaku: Darehitori torinokosanai tameni (Health support and medical interpretation for foreign residents in Japan: To leave no one behind). Tokyo: Kyorin Shoin; 2018. p. 45-9.

22. Aichi Medical Interpretations System, Aichi prefecture. Iryokikan nado gaikokujin taio manyuaru Soron [in Japanese] (A manual for medical institutions how to accept foreign patients General information). Nagoya: Aichi Medical Interpretations System, Aichi prefecture. [Cited 9 Dec 2020]; Available from: http://www.aichi-iryou-tsuyaku-system.com/manual/data/japanese/1/manual1-1a.pdf. 
23. Sawada T. Gaikokujin to issyo ni kakusa wo umeyo [in Japanese] (Fill the health gap with foreign residents). Chiryo. 2017;99(1):79-83.

24. Yasukawa K, Sawada T, Hashimoto H, Jimba M. Health-care disparities for foreign residents in Japan. The Lancet. 2019;393(10174):873-4.

25. Parikh N. Migrant health in Japan; Safety-net policies and advocates' policy solutions. The Asia-Pacific Journal: Japan Focus. 2010;8(12):3.

26. Yamanaka K. Migration, differential access to health services and civil society's responses in Japan. In: Santosh J, Toyota M, Yeo BSA, editors. Migration and health in Asia. London: Routledge; 2006. p. 141-60.

27. Tsutsumi K. Gaikokujin rodosya to sonokazoku heno iryoshien - Aichi-ken Toyota-shi no jirei wo chushin ni [in Japanese] (Medical support for foreign workers and their families - Focusing on a case report in Toyota, Aichi). The Reference. 2007(673):66-76.

28. Japan Students Services Organization. Result of an annual survey of international students in Japan 2019. Japan Student Services Organization; 2020. [Cited 9 Dec 2020]; Available from: https://studyinjapan.go.jp/en/_mt/2020/08/date2019z_e.pdf.

29. Association for the Promotion of Japanese Language Education. Heisei-21-nendo nihongo kyoikukikan gakuseiseikatsu jittai chosa [in Japanese] (A survey on the current living conditions of students studying in Japanese language institutes in Fiscal 2009). Tokyo: Association for the Promotion of Japanese Language Education; 2010. [Cited 9 Dec 2020]; Available from: http://www.nisshinkyo.org/article/pdf/overview03.pdf.

30. Shakya P, Sawada T, Zhang H, Kitajima T. Factors associated with access to HIV testing among international students in Japanese language schools in Tokyo. PLoS One. 2020;15(7):e0235659.

31. "Hairisukusya no kekkaku taisaku” kenkyuhan ("Tuberculosis control for the high-risk populations" Research Group). Nihongogakko kekkaku kenshin no arikata ni kansuru teigen [in Japanese] (Recommendations of tuberculosis screening in Japanese language schools). Tokyo: The Research Institute of Tuberculosis, Japan Anti-Tuberculosis Association; 2017. [Cited 9 Dec 2020]; Available from: https://jata.or.jp/dl/pdf/data/arikata_20180309.pdf.

32. Kawatsu R. Yunyukansensho toshiteno kekkaku [in Japanese] (Tuberculosis as an imported infectious disease). Infectious Agents Surveillance Report. 2017;38:234-5

33. Japan Students Services Organization. Heisei-29-nendo shihi gaikokujin ryugakusei seikatsu jittai chosa [in Japanese] (A survey on the current living conditions of privately-funded foreign students in Fiscal 2017). Tokyo: Japan Students Services Organization; 2019. [Cited 9 Dec 2020]; Available from: https://www.studyinjapan.go.jp/ja/_mt/2020/08/seikatsu2017.pdf.

34. Zairyugaikokujin tokei, hyobango 16-12-05-0 [in Japanese] (Statistics on foreign residents, Table No.16-12-05-0) [Internet]. Official Statistics of Japan. 2017. Available from: https://www.e-stat.go.jp/stat-search/files?

page $=1$ \&layout $=$ dataset\&toukei $=00250012 \&$ bunya_l=02\&tstat $=000001018034 \&$ cycle $=1 \&$ year=20160\&tclass $1=000001060399 \&$ stat_infid $=000031559331$

35. Sioson EP. Uneven integration: Local government integration policies and Filipino residents in Nagoya City, Japan. Asia \& the Pacific Policy Studies. 2017;4(3):496-513.

36. Aichi Prefectural Office. Aichi-kennai no shichoson ni okeru gaikokujin juminsu no jokyo (Heisei-28-nen 12-gatsu matsu genzai) [in Japanese] (The number of foreign residents in Aichi Prefecture (as of the end of December, 2016)): Aichi Prefectural Office; 2017. [Cited 9 Dec 2020]; Available from: https://www.pref.aichi.jp/soshiki/tabunka/gaikokuzinjuminsu-h28-12.html.

37. Muhib FB, Lin LS, Stueve A, Miller RL, Ford WL, Johnson WD, et al. A venue-based method for sampling hard-to-reach populations. Public Health Reports. 2001;116(SUPPL. 1):216-22.

38. Nomura Y, Poudel KC, Jimba M. Hard-to-reach populations in Japan. Southeast Asian J Trop Med Public Health. 2007;38(2):325-7.

39. Kobori E, Maeda Y, Yamamoto T. [Mortality rates of foreign national residents in Japan: comparison with the Japanese population and a possible healthy migrant effect]. Nihon Koshu Eisei Zasshi. 2017;64(12):707-17.

40. Miller R, Tomita Y, Ong KIC, Shibanuma A, Jimba M. Mental well-being of international migrants to Japan: a systematic review. BMJ Open. 2019;9(11):e029988.

41. Institute of Medicine Committee on Monitoring Access to Personal Health Care Services. Access to health care in America. Washington (DC): National Academic Press; 1993. Available from: https://www.ncbi.nlm.nih.gov/books/NBK235882/.

42. OECD. Unmet needs for healthcare: Comparing approaches and results from international surveys. OECD; 2020. [Cited 9 Dec 2020]; Available from: https://www.oecd.org/health/health-systems/Unmet-Needs-for-Health-Care-Brief-2020.pdf.

43. Minister's Secretariat Ministry of Home Affairs Japan. Chiiki kokusaikoryu suisintaiko oyobi jichitai kokusaikyoryoku suisintaiko ni okeru minkandantai no ichiduke ni tsuite [in Japanese] (About positions of non-govenmental organizations in outline of the promotion of international exchange in the community and outline of promotion of the international collabolation in local governments). Tokyo: Ministry of Home Affairs Japan; 2000 . [Cited 9 Dec 2020]; Available from: https://www.soumu.go.jp/kokusai/pdf/sonota_b3.pdf.

44. Tabunkakyosei jireisyu sakusei waking gurupu (Working Group for compiling case reports on multicultural coexistance). Tabunkakyosei jireisyu Tabunkakyosei puran kara 10-nen Tomoni hiraku chiiki no mirai - [in Japanese] (Case reports on multicultural coexistance - 10 years after multicultural coexistance plans Community's future to be developed together -) Tokyo: MInistry of Internal Affairs and Communications, Japan; 2017. [Cited 9 Dec 2020]; Available from: https://www.soumu.go.jp/main_content/000476646.pdf. 